Prepared in cooperation with the Triangle Area Water Supply Monitoring Project Steering Committee

\title{
Triangle Area Water Supply Monitoring Project, North Carolina-Summary of Monitoring Activities, Quality Assurance, and Data, October 2015-September 2017
}

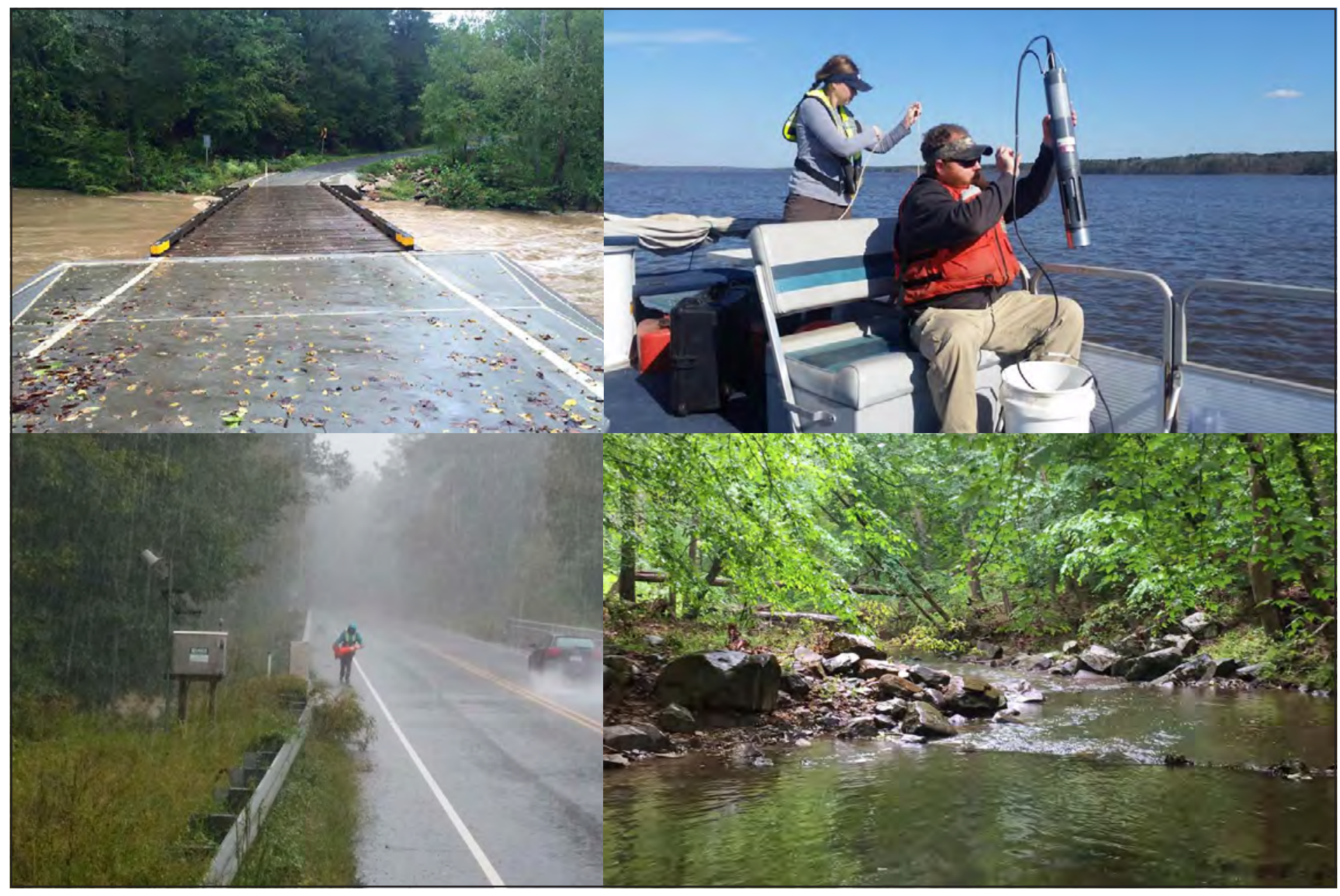

Open-File Report 2019-1077 
Flat River at Bahama, North Carolina (U.S. Geological Survey streamgaging station 02085500). Photograph by Jessica L. Cain, U.S. Geological Survey.

New Hope Creek near Blands, North Carolina (U.S. Geological Survey streamgaging station 02097314). Photograph by Ryan B. Rasmussen, U.S. Geological Survey.
B.E. Jordan Lake above U.S. Highway 64 at Wilsonville, North Carolina (U.S. Geological Survey streamgaging station 0209799150). Photograph by Erik L. Staub, U.S. Geological Survey.

Morgan Creek near White Cross, North Carolina (U.S. Geological Survey streamgaging station 02097464). Photograph by Jessica L. Cain, U.S. Geological Survey. 


\section{Triangle Area Water Supply Monitoring Project, North Carolina-Summary of Monitoring Activities, Quality Assurance, and Data, October 2015-September 2017}

By C.A. Pfeifle, J.L. Cain, and R.B. Rasmussen

Prepared in cooperation with the Triangle Area Water Supply Monitoring Project Steering Committee

Open-File Report 2019-1077 


\title{
U.S. Department of the Interior DAVID BERNHARDT, Secretary
}

\author{
U.S. Geological Survey \\ James F. Reilly II, Director
}

U.S. Geological Survey, Reston, Virginia: 2019

For more information on the USGS - the Federal source for science about the Earth, its natural and living resources, natural hazards, and the environment-visit https://www.usgs.gov or call 1-888-ASK-USGS (1-888-275-8747).

For an overview of USGS information products, including maps, imagery, and publications, visit https://store.usgs.gov.

Any use of trade, firm, or product names is for descriptive purposes only and does not imply endorsement by the U.S. Government.

Although this information product, for the most part, is in the public domain, it also may contain copyrighted materials as noted in the text. Permission to reproduce copyrighted items must be secured from the copyright owner.

Suggested citation:

Pfeifle, C.A., Cain, J.L., and Rasmussen, R.B., 2019, Triangle Area Water Supply Monitoring Project, North CarolinaSummary of monitoring activities, quality assurance, and data, October 2015-September 2017: U.S. Geological Survey Open-File Report 2019-1077, 16 p., https://doi.org/10.3133/ofr20191077.

ISSN 2331-1258 (online) 


\section{Contents}

Abstract

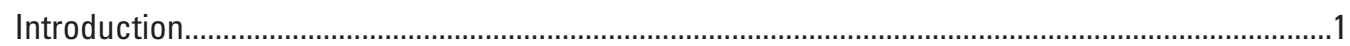

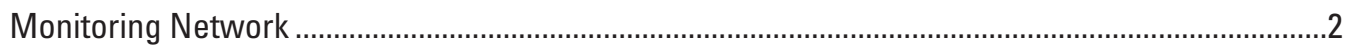

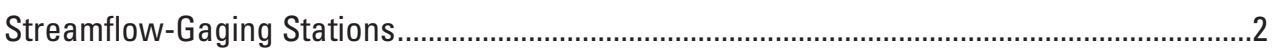

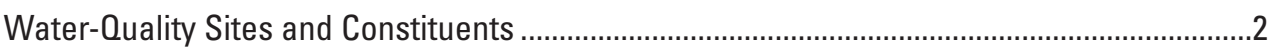

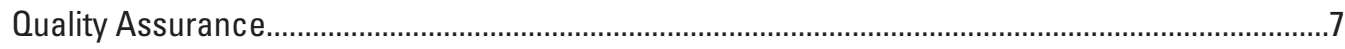

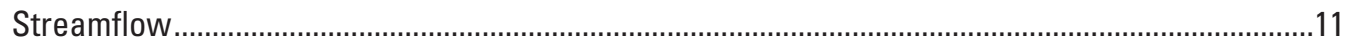

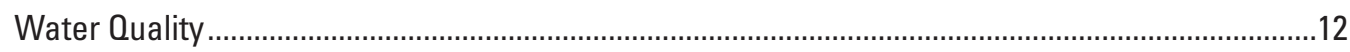

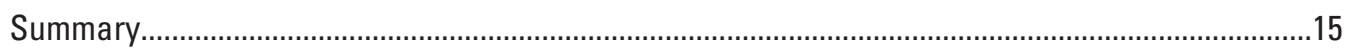

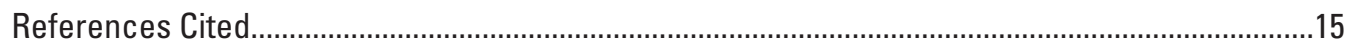

\section{Figures}

1. Map showing location of Triangle Area Water Supply Monitoring Project data-collection sites in the upper Cape Fear and Neuse River Basins,

North Carolina, October 2015 through September 2017...

2. Graphs showing annual runoff measured from 0 ctober 2015 through September 2016 and October 2016 through September 2017, and the long-term mean runoff for the period of record at 10 streamflow-gaging stations in the Triangle area of North Carolina

3. Maps showing sites in the Triangle area of North Carolina with one or more measurements of dissolved-oxygen concentration less than 5 milligrams per liter, dissolved-oxygen percent saturation values greater than 110 percent, $\mathrm{pH}$ values greater than 9 standard units, water temperature values greater than 32 degrees Celsius, turbidity values greater than 25 nephelometric turbidity ratio units for lakes and reservoirs or greater than 50 nephelometric turbidity ratio units for streams, and concentrations of chlorophyll a greater than 40 micrograms per liter, October 2015 through September 2017.

\section{Tables}

1. Water-quality and streamflow monitoring sites for the Triangle Area Water Supply Monitoring Project, North Carolina, October 2015 through September 2017.

2. Physical properties measured in the field and chemical constituents analyzed at the National Water Quality Laboratory for the Triangle Area Water Supply Monitoring Project, and the methods used for analyses, October 2015-September 2017

3. Summary of selected constituent data observed in blank and environmental samples from the Triangle Area Water Supply Monitoring Project, October 2015 through September 2017.

4. Summary of chlorophyll a triplicate sample sets from the Triangle Area Water Supply Monitoring Project, October 2015 through September 2017

5. Summary of water-quality results for sampled sites in the Triangle Area Water Supply Monitoring Project, October 2015 through September 2017 


\section{Conversion Factors}

\begin{tabular}{|c|c|c|}
\hline Multiply & By & To obtain \\
\hline \multicolumn{3}{|c|}{ Length } \\
\hline inch (in.) & 25.4 & millimeter (mm) \\
\hline mile (mi) & 1.609 & kilometer $(\mathrm{km})$ \\
\hline \multicolumn{3}{|c|}{ Flow rate } \\
\hline cubic foot per second $\left(\mathrm{ft}^{3} / \mathrm{s}\right)$ & 0.02832 & cubic meter per second $\left(\mathrm{m}^{3} / \mathrm{s}\right)$ \\
\hline
\end{tabular}

Temperature in degrees Celsius $\left({ }^{\circ} \mathrm{C}\right)$ may be converted to degrees Fahrenheit $\left({ }^{\circ} \mathrm{F}\right)$ as

$$
{ }^{\circ} \mathrm{F}=\left(1.8 \times{ }^{\circ} \mathrm{C}\right)+32 \text {. }
$$

\section{Supplemental Information}

Water year is defined as the period from 0ctober 1 to September 30 and is identified by the year in which the period ends. For example, water year 2016 is 0 ctober 1, 2015, to September 30, 2016.

Specific conductance is given in microsiemens per centimeter at 25 degrees Celsius $\left(\mu \mathrm{S} / \mathrm{cm}\right.$ at $\left.25^{\circ} \mathrm{C}\right)$.

Concentrations of chemical constituents in water are given either in milligrams per liter (mg/L) or micrograms per liter $(\mu \mathrm{g} / \mathrm{L})$.

\section{Abbreviations}

$\begin{array}{ll}\text { NCDWR } & \text { North Carolina Division of Water Resources } \\ \text { NWISWeb } & \text { USGS National Water Information System } \\ \text { NWQL } & \text { USGS National Water Quality Laboratory } \\ \text { RPD } & \text { relative percent difference } \\ \text { TAWSMP } & \text { Triangle Area Water Supply Monitoring Project } \\ \text { USGS } & \text { U.S. Geological Survey }\end{array}$




\title{
Triangle Area Water Supply Monitoring Project, North Carolina-Summary of Monitoring Activities, Quality Assurance, and Data, October 2015-September 2017
}

\author{
By C.A. Pfeifle, J.L. Cain, and R.B. Rasmussen
}

\section{Abstract}

Surface-water supplies are important sources of drinking water for residents in the Triangle area of North Carolina, which is located within the upper Cape Fear and Neuse River Basins. Since 1988, the U.S. Geological Survey and a consortium of local governments have tracked water-quality conditions and trends in several of the area's water-supply lakes and streams. This report summarizes data collected through this cooperative effort, known as the Triangle Area Water Supply Monitoring Project, during October 2015 through September 2016 (water year 2016) and October 2016 through September 2017 (water year 2017). Major findings for this period include the following:

- More than 5,000 individual measurements of water quality were made at a total of 20 sites -7 in the Neuse River Basin and 13 in the Cape Fear River Basin. Only the measurements from the photic zone and 1 meter below the water surface are documented in this report.

- Twenty-nine water-quality properties or constituents are presented in this report; State water-quality thresholds exist for 11 of these.

- All observations met State water-quality thresholds for hardness, chloride, fluoride, sulfate, and nitrate plus nitrite.

- North Carolina water-quality thresholds were exceeded one or more times for dissolved oxygen, dissolvedoxygen percent saturation, $\mathrm{pH}$, water temperature, turbidity, and chlorophyll $a$.

\section{Introduction}

The Triangle area, located within the upper Cape Fear and Neuse River Basins, is one of the most rapidly developing areas of North Carolina. Population growth continues to increase demands for water from public suppliers, the majority of which draw water from streams and lakes in the region. Growth also brings the threat of greater loads of pollutants and new contaminant sources which, if not properly managed, could adversely affect water quality.

The Triangle Area Water Supply Monitoring Project (TAWSMP) has tracked water-quality conditions and longterm trends in many of the area's water-supply lakes, rivers, and tributaries for almost 30 years. The project has progressed in phases, allowing for flexibility in the monitoring network and partners and for timely response to emerging water-quality concerns. Objectives of the project for water years 2016 and 2017 were as follows:

- Extend the existing water-quality database for nutrients, sediment, major ions, and selected metals to track spatial variations in water quality, loads to reservoirs, and long-term water-quality trends.

- Continue monitoring at tributary sites during high-flow events to increase the understanding of constituent concentrations and loads during extreme hydrologic conditions.

- Maintain a network of 10 continuous streamflowgaging stations in the study area.

Pursuant to an agreement with several local governments, the U.S. Geological Survey (USGS) monitors hydrologic conditions and collects water-quality samples. One site in the Triangle area consists only of a streamflow gage. Continuous streamflow is recorded at most of the stream sites and is funded through the TAWSMP and other USGS programs. The USGS is responsible for data quality assurance, analysis, and interpretation; providing the data to the public; and maintaining the data in perpetuity. Funding for the project is provided by local government partners (see sidebar) and by the USGS (https://www.usgs.gov/mission-areas/ water-resources/science/usgs-cooperative-matching-funds?qtscience_center_objects $=0 \#$ qt-science_center_objects). The Triangle J Council of Governments provides organizational support services for the TAWSMP. 
Triangle Area Water Supply Monitoring Project
Partners, 2016-17

Chatham County

Orange County

Town of Apex

Town of Cary

City of Durham

Town of Hillsborough

Town of Morrisville

Orange Water and Sewer Authority

Triangle J Council of Governments

U.S. Geological Survey

For more information on the project, go to

https://tawsmp.org/.

This report summarizes monitoring activities and data collected by the USGS for the TAWSMP during October 2015 through September 2017, also referred to as water years 2016 (October 2015 to September 2016) and 2017 (October 2016 to September 2017). Hydrologic conditions in the Triangle area are described. Ranges of concentrations for water-quality in situ measurements, major ions, nutrients, unfiltered iron and manganese, total organic carbon, chlorophyll $a$, and suspended sediment are presented for each site sampled during this period. The supporting data for this report are available at Cain and others (2019; https://doi.org/10.5066/F71Z43MD).

\section{Monitoring Network}

Since the project began in 1988, several adjustments have been made to sampling locations, sampling frequency, and constituents that are sampled. During 2016-17, the TAWSMP monitoring network was composed of 22 sites, including streamflow-gaging stations and stream and lake water-quality sampling sites (fig. 1). Water-quality samples were collected at 20 sites during this period. Project sampling and analytical methods and quality-assurance practices are described in Oblinger (2004).

In August 2017, sample collection at Little River Reservoir (site 5) and Lake Michie (site 7) resumed under a new 5-year agreement with the Triangle J Council of Governments that began in July. Data collection for bromide, chromium (hexavalent, filtered, and total), and 1,4-dioxane started under the new agreement, and analysis for pheophytin was resumed. Data for these new constituents will be presented in future reports, starting with water years 2018 and 2019. The data collected as part of this project are available to project partners and the public through the USGS National Water Information System (NWISWeb) database (U.S. Geological Survey,
2018; https://doi.org/10.5066/F7P55KJN), Cain and others (2019; https://doi.org/10.5066/F71Z43MD), or by request from the USGS South Atlantic Water Science Center (https://www.usgs.gov/centers/sa-water).

\section{Streamflow-Gaging Stations}

Streamflow records are useful for managing water supplies and are essential for determining instream loads of sediment, nutrients, and other constituents and interpreting water-quality trends. The USGS operates 10 continuous-record streamflowgaging stations that are funded through the TAWSMP (table 1). These gages record water levels at 15-minute intervals and display them and calculated discharge in near-real time through the USGS NWISWeb database (U.S. Geological Survey, 2018; https://doi.org/10.5066/F7P55KJN). Precipitation and streamflow data for additional sites in the study area are available through other USGS programs (table 1).

\section{Water-Quality Sites and Constituents}

Water-quality data are used to track current conditions and to analyze long-term water-quality trends and pollutant loads in the Triangle area. The USGS monitored water quality at 20 sites in the TAWSMP study area during water years 2016 and 2017. More than 5,000 individual measurements of water quality were made. The analytical methods used to measure the physical properties and chemical constituents analyzed for this project are presented in table 2. Measurements were made at 7 sites in the Neuse River Basin and 13 sites in the Cape Fear River Basin.

Nine sites at six public water-supply lakes were sampled including West Fork Eno River Reservoir (site 1), Little River Reservoir (site 5), and Lake Michie (site 7) in the Neuse River Basin, and Cane Creek Reservoir (site 9), University Lake (site 15), and Jordan Lake (sites 11, 18, 20, 21) in the Cape Fear River Basin (table 1; fig. 1). Jordan Lake is a large, multipurpose reservoir managed by the U.S. Army Corps of Engineers. Three sites in Jordan Lake (sites 18, 20, and 21) were sampled bimonthly during water years 2016 and 2017, and site 11 was sampled four times per year. The five smaller reservoirs are used primarily for water supply; three also provide recreational access. One site in each of the smaller lakes was sampled four times (October, April, June, and August) per year.

Lake samples were collected at multiple depths, but only the samples collected at the photic zone and 1 meter (m) below the water surface are summarized in this report. Vertical profiles of field parameters (dissolved oxygen, $\mathrm{pH}$, specific conductance, and water temperature) were measured at 1-m depth intervals at the sampling location, along with water transparency, which was measured by Secchi disk. Water samples were collected for analysis of turbidity, acid neutralizing capacity, major ions (calcium, magnesium, potassium, sodium, chloride, fluoride, silica, and sulfate), nutrients (ammonia plus organic nitrogen, ammonia, nitrate 


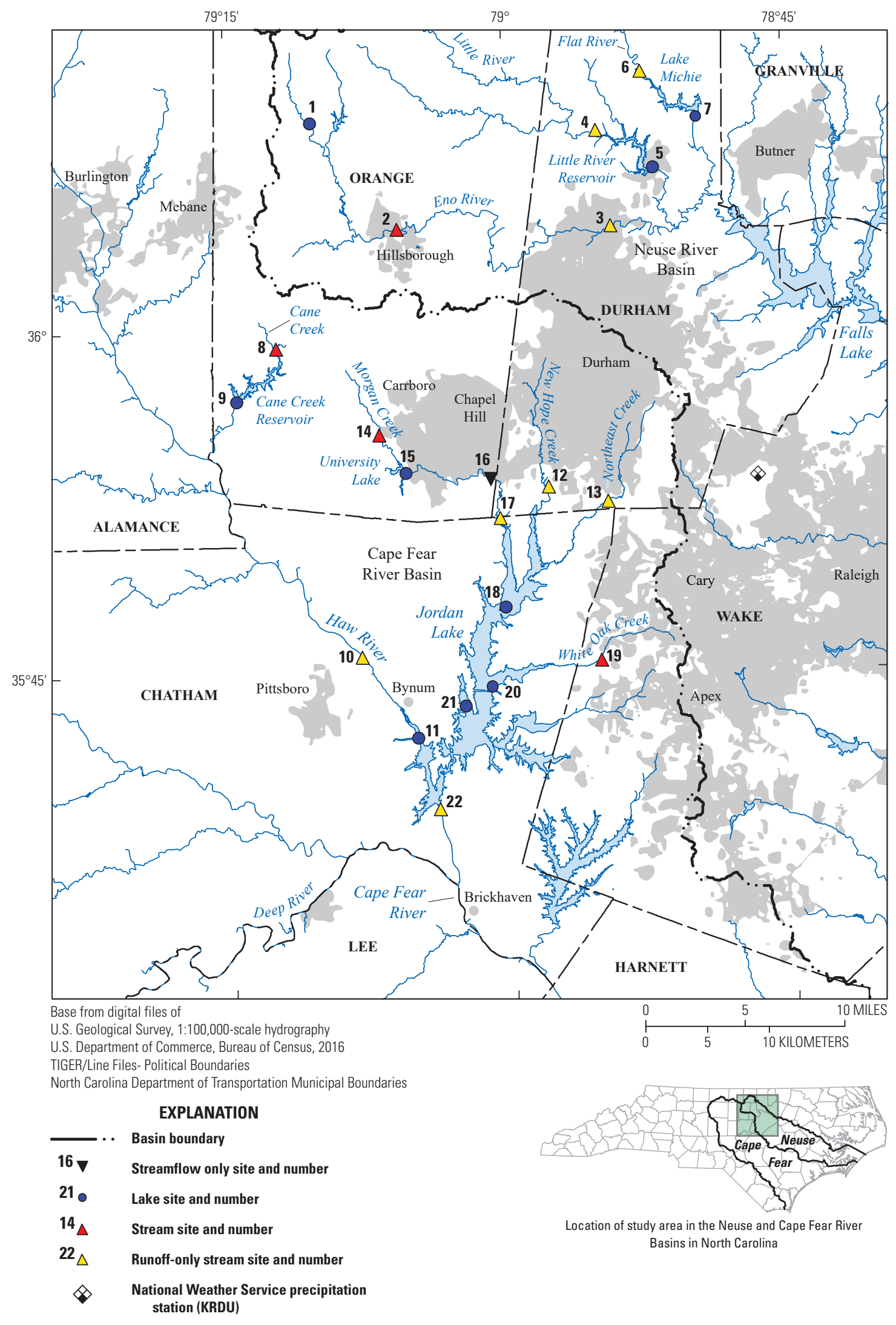

Figure 1. Map showing location of Triangle Area Water Supply Monitoring Project data-collection sites in the upper Cape Fear and Neuse River Basins, North Carolina, October 2015 through September 2017. 
Table 1. Water-quality and streamflow monitoring sites for the Triangle Area Water Supply Monitoring Project, North Carolina, October 2015 through September 2017.

[USGS, U.S. Geological Survey; Lake, lake sites that were sampled bimonthly; Stream (routine), stream sites that were sampled bimonthly and during runoff; Stream (runoff), stream sites that were sampled only during runoff events; $\mathrm{n} / \mathrm{a}$, not applicable for lake sites; - , data were not collected (refer to footnote); SR, Secondary Road; USACE, U.S. Army Corps of Engineers]

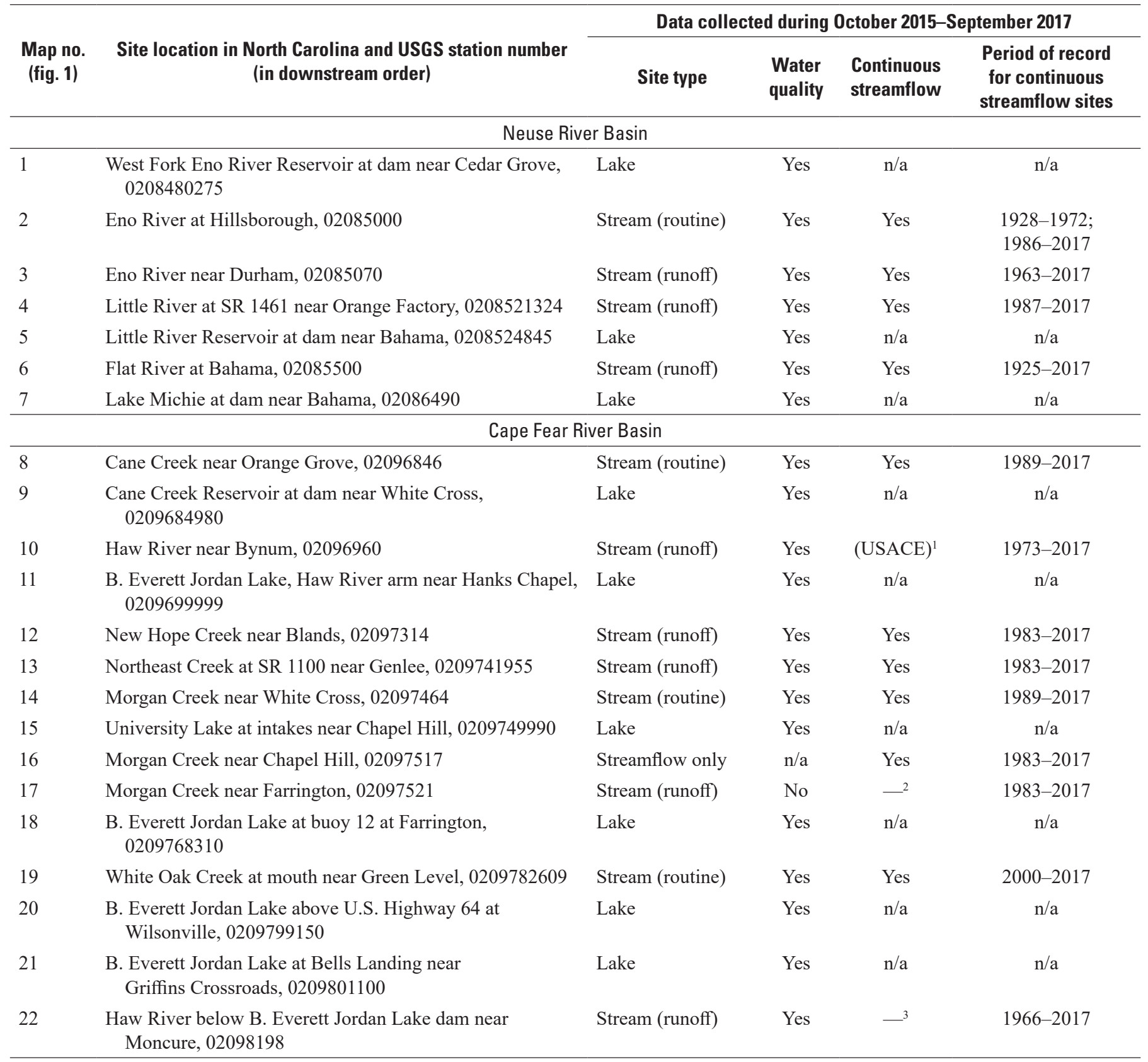

${ }^{1}$ Gage funded through separate agreement with the U.S. Army Corps of Engineers.

${ }^{2}$ Streamflow from nearby gage, USGS station 02097517.

${ }^{3}$ Streamflow computed from USACE releases from the Jordan Lake dam. 
Table 2. Physical properties measured in the field and chemical constituents analyzed at the National Water Quality Laboratory (NWOL) for the Triangle Area Water Supply Monitoring Project, and the methods used for analyses, October 2015-September 2017.

$\left[{ }^{\circ} \mathrm{C}\right.$, degree Celsius; USGS, U.S. Geological Survey; m, meter; $\mu \mathrm{S} / \mathrm{cm}$ at $25^{\circ} \mathrm{C}$, microsiemens per centimeter at 25 degrees Celsius; $\mathrm{mg} / \mathrm{L}$, milligram per liter; $\mathrm{pH}$, negative log (base 10 ) of the hydrogen ion activity; $\mathrm{CaCO}_{3}$, calcium carbonate; $\mathrm{N}$, nitrogen; $\mathrm{P}$, phosphorus; $\mathrm{SiO}_{2}$, silicon dioxide; $\mu \mathrm{g} / \mathrm{L}$, microgram per liter; DA, (automated) discrete analyzer; ASF, automated segmented flow]

\begin{tabular}{|c|c|c|c|c|c|}
\hline Physical property or constituent & $\begin{array}{l}\text { Parameter } \\
\text { code }\end{array}$ & $\begin{array}{l}\text { Method } \\
\text { code }\end{array}$ & Method reference & Analytical method & $\begin{array}{l}\text { Analyzing } \\
\text { entity }\end{array}$ \\
\hline Transparency, Secchi, (m) & 00078 & SECCH & $\begin{array}{l}\text { Hambrook Berkman and } \\
\text { Canova (2007) }\end{array}$ & Secchi disk & Field \\
\hline Dissolved oxygen, $(\mathrm{mg} / \mathrm{L})$ & 00300 & LUMIN & Rounds and others (2013) & Electrometry, luminescence quenching & Field \\
\hline $\mathrm{pH}$, in standard units & 00400 & PROBE & Ritz and Collins (2008) & Electrometry, ion-selective electrode & Field \\
\hline Specific conductance, $\left(\mu \mathrm{S} / \mathrm{cm}\right.$ at $\left.25^{\circ} \mathrm{C}\right)$ & 00095 & SC001 & Radtke and others (2005) & Electrometry, Wheatstone bridge & Field \\
\hline Temperature, water, $\left({ }^{\circ} \mathrm{C}\right)$ & 00010 & THM01 & Wilde (2006) & Thermistor & Field \\
\hline Turbidity, (NTU) & 63676 & TS196 & O’Dell (1993) & Nephelometry & Field \\
\hline Calcium, filtered, $(\mathrm{mg} / \mathrm{L})$ & 00915 & PLA11 & Fishman (1993) & $\begin{array}{l}\text { Atomic emission spectrometry, inductively } \\
\text { coupled plasma }\end{array}$ & NWQL \\
\hline Magnesium, filtered, (mg/L) & 00925 & PLA11 & Fishman (1993) & $\begin{array}{l}\text { Atomic emission spectrometry, inductively } \\
\text { coupled plasma }\end{array}$ & NWQL \\
\hline Potassium, filtered, (mg/L) & 00935 & PLO03 & Clesceri and others (1998b) & $\begin{array}{l}\text { Atomic emission spectrometry, inductively } \\
\text { coupled plasma }\end{array}$ & NWQL \\
\hline Sodium, filtered, (mg/L) & 00930 & PLA11 & Fishman (1993) & $\begin{array}{l}\text { Atomic emission spectrometry, inductively } \\
\text { coupled plasma }\end{array}$ & NWQL \\
\hline Acid neutralizing capacity (ANC), (mg/L as $\mathrm{CaCO} 3)$ & 00419 & TT065 & Rounds (2012) & $\begin{array}{l}\text { Electrometry, ion-selective electrode, titration or } \\
\text { pH } 4.5\end{array}$ & NWQL \\
\hline Bicarbonate, unfiltered, (mg/L as $\mathrm{CaCO} 3)$ & 00450 & ASM09 & Rounds (2012) & $\begin{array}{l}\text { Electrometry, ion-selective electrode, incremental } \\
\text { titration }\end{array}$ & NWQL \\
\hline Chloride, filtered, (mg/L) & 00940 & $\mathrm{IC} 022$ & Fishman and Friedman (1989) & Conductivity, ion-exchange chromatography & NWQL \\
\hline Fluoride, filtered, $(\mathrm{mg} / \mathrm{L})$ & 00950 & IC003 & Fishman and Friedman (1989) & Conductivity, ion-exchange chromatography & NWQL \\
\hline Silica, filtered, (mg/L as $\mathrm{SiO} 2)$ & 00955 & PLA11 & Fishman (1993) & $\begin{array}{l}\text { Atomic emission spectrometry, inductively } \\
\text { coupled plasma, digestion }\end{array}$ & NWQL \\
\hline Sulfate, filtered, $(\mathrm{mg} / \mathrm{L})$ & 00945 & IC022 & Fishman and Friedman (1989) & Conductivity, ion-exchange chromatography & NWQL \\
\hline Residue on evaporation at 180 degrees $\mathrm{C}$, filtered, $(\mathrm{mg} / \mathrm{L})$ & 70300 & ROE10 & Fishman and Friedman (1989) & Gravimetry/evaporation at $180^{\circ} \mathrm{C}$ & NWQL \\
\hline Ammonia plus organic nitrogen, unfiltered, (mg/L as $\mathrm{N})$ & 00625 & KJ008 & Patton and Truitt (2000) & $\begin{array}{l}\text { Colorimetry, ASF, micro-Kjeldahl digestion, } \\
\text { acidified }\end{array}$ & NWQL \\
\hline Ammonia, filtered, (mg/L as $\mathrm{N})$ & 00608 & $\mathrm{SHC} 02$ & Fishman (1993) & Colorimetry, DA, salicylate-hypochlorite & NWQL \\
\hline Nitrate plus nitrite, filtered, $(\mathrm{mg} / \mathrm{L}$ as $\mathrm{N})$ & 00631 & RED02 & Patton and Kryskalla (2011) & $\begin{array}{l}\text { Colorimetry, DA, enzymatic reduction-diazotiza- } \\
\text { tion, filtered, low-level }\end{array}$ & NWQL \\
\hline Orthophosphate, filtered, (mg/L as P) & 00671 & PHM01 & Fishman (1993) & Colorimetry, DA, phosphomolybdate & NWQL \\
\hline
\end{tabular}

Orthophosphate, filtered, $(\mathrm{mg} / \mathrm{L}$ as $\mathrm{P})$

Colorimetry, DA, phosphomolybdate 
Table 2. Physical properties measured in the field and chemical constituents analyzed at the National Water Quality Laboratory (NWOL) for the Triangle Area Water Supply Monitoring Project, and the methods used for analyses, October 2015-September 2017.-Continued

$\left[{ }^{\circ} \mathrm{C}\right.$, degree Celsius; USGS, U.S. Geological Survey; m, meter; $\mu \mathrm{S} / \mathrm{cm}$ at $25^{\circ} \mathrm{C}$, microsiemens per centimeter at 25 degrees Celsius; $\mathrm{mg} / \mathrm{L}$, milligram per liter; $\mathrm{pH}$, negative log (base 10 ) of the hydrogen ion activity; $\mathrm{CaCO}_{3}$, calcium carbonate; $\mathrm{N}$, nitrogen; $\mathrm{P}$, phosphorus; $\mathrm{SiO}_{2}$, silicon dioxide; $\mu \mathrm{g} / \mathrm{L}$, microgram per liter; DA, (automated) discrete analyzer; ASF, automated segmented flow]

\begin{tabular}{|c|c|c|c|c|c|}
\hline Physical property or constituent & $\begin{array}{l}\text { Parameter } \\
\text { code }\end{array}$ & $\begin{array}{l}\text { Method } \\
\text { code }\end{array}$ & Method reference & Analytical method & $\begin{array}{c}\text { Analyzing } \\
\text { entity }\end{array}$ \\
\hline Phosphorus, unfiltered, (mg/L as P) & 00665 & CL021 & $\begin{array}{l}\text { U.S. Environmental Agency } \\
\text { (1993) }\end{array}$ & $\begin{array}{l}\text { Colorimetry, ASF, alkaline-persulfate digestion, } \\
\text { low level }\end{array}$ & NWQL \\
\hline Total organic carbon, unfiltered, $(\mathrm{mg} / \mathrm{L})$ & 00680 & COMB9 & Clesceri and others (1998a) & $\begin{array}{l}\text { Non-dispersive infrared analysis, high } \\
\text { temperature combustion }\end{array}$ & NWQL \\
\hline Chlorophyll $a$, filtered $(\mu \mathrm{g} / \mathrm{L})$ & 70953 & FL008 & Arar and Collins (1997) & Chromatographic-fluorometric method & $\begin{array}{l}\text { Meritech, } \\
\text { Inc. }\end{array}$ \\
\hline Chlorophyll $a$, filtered $(\mu \mathrm{g} / \mathrm{L})$ & 70953 & FL0016 & Arar and Collins (1997) & Chromatographic-fluorometric method & NWQL \\
\hline Iron, unfiltered, recoverable, $(\mu \mathrm{g} / \mathrm{L})$ & 01045 & PLO07 & Garbarino and Struzeski (1998) & $\begin{array}{l}\text { Atomic emission spectrometry, inductively } \\
\text { coupled plasma, digestion }\end{array}$ & NWQL \\
\hline Manganese, unfiltered, recoverable, $(\mu \mathrm{g} / \mathrm{L})$ & 01055 & PLO07 & Garbarino and Struzeski (1998) & $\begin{array}{l}\text { Mass spectrometry, inductively coupled plasma, } \\
\text { digestion }\end{array}$ & NWQL \\
\hline Suspended sediment, $(\mathrm{mg} / \mathrm{L})$ & 80154 & SED10 & $\begin{array}{l}\text { American Society for Testing } \\
\text { and Materials (2002) }\end{array}$ & Gravimetric/filtration & NWQL \\
\hline
\end{tabular}


plus nitrite, orthophosphate, and phosphorus), total organic carbon, chlorophyll $a$, and unfiltered iron and manganese during each sampling trip (Oblinger, 2004). In this report, turbidity values are reported in nephelometric turbidity ratio units (NTRU). Ammonia plus organic nitrogen, ammonia, and nitrate plus nitrite are reported in milligrams per liter as nitrogen $(\mathrm{mg} / \mathrm{L}$ as $\mathrm{N})$, and orthophosphate and phosphorus are reported in milligrams per liter as phosphorus $(\mathrm{mg} / \mathrm{L}$ as $\mathrm{P})$.

Four stream sites were sampled by the USGS on a bimonthly basis to measure water-quality field properties, major ions, nutrients, total organic carbon, and suspended sediment. These sites include Eno River at Hillsborough (site 2), Cane Creek near Orange Grove (site 8), Morgan Creek near White Cross (site 14), and White Oak Creek (site 19, fig. 1; table 1). Samples were collected at multiple locations along a transect and were composited. Sampling was not conducted during no-flow conditions, which occasionally occurred at the smaller streams. During water years 2016 and 2017, routine sampling at the nine lake sites and the four bimonthly stream sites was conducted on schedule.

In addition to bimonthly sampling at the four stream sites, an additional eight stream sites in the TAWSMP network were considered for sampling only during storm-runoff events when water levels were rapidly increasing because of localized rainfall events. During 2016-17, four additional stream sites were sampled by the USGS during selected storm-runoff events including Haw River near Bynum (site 10), New Hope Creek near Blands (site 12), Northeast Creek near Genlee (site 13), and Haw River below B. Everett Jordan Lake dam near Moncure (site 22). These higher-flow samples supplement fixed-interval data collected by the North Carolina Division of Water Resources (NCDWR) as part of the Ambient Monitoring System (https://deq.nc.gov/about/divisions/ water-resources/water-resources-data/water-sciences-homepage/ecosystems-branch/ambient-monitoring-system). It is important to note that results for the four streams sampled only during runoff events likely do not represent typical water-quality conditions for these streams.

Acid neutralizing capacity was determined in the field at the time of sampling by using USGS standard methods (Rounds, 2012). Nutrient and major ions analyses were performed at the USGS National Water Quality Laboratory (NWQL) in Denver, Colorado. Water samples were analyzed for suspended sediment concentrations at the USGS Eastern Region Sediment Laboratory in Louisville, Kentucky.

The majority of chlorophyll $a$ analyses for water years 2016 and 2017 were performed by Meritech, Inc., in Reidsville, N.C., and the chlorophyll $a$ analyses for August 2017 were performed by the USGS NWQL. Both laboratories participated in the chlorophyll $a$ interlaboratory performance comparisons (round robins) sponsored by the NCDWR during 2016 and 2017 and demonstrated acceptable performance. Under the new 5-year agreement with the Triangle J Council of Governments, the NWQL resumed analyzing of the chlorophyll $a$ and pheophytin samples after being accredited by the State of North Carolina.

\section{Quality Assurance}

Quality-control samples, consisting of equipment blanks, sampling-vehicle (ambient) blanks, field blanks, and replicate samples, were collected, analyzed, and reviewed throughout the period to ensure that project data-quality objectives were met (Oblinger, 2004). The source solution for sampling-vehicle and field blanks was inorganic-blank or organic-blank water (depending on the constituents to be analyzed) obtained from the USGS National Field Supply Service. Approximately 18 percent of the total samples collected during the study period consisted of quality-control samples. Quality-control samples and collection procedures are described in chapter A4 of the USGS National Field Manual (U.S. Geological Survey, 2006). Quality-assurance data for this report are available at Cain and others (2019; https://doi.org/10.5066/F71Z43MD).

Six equipment blanks, eight sampling-vehicle blanks, and 13 field blanks were collected and analyzed during October 2015 through September 2017 for major ions, nutrients, trace metals, chlorophyll $a$, total organic carbon, and suspended sediment. In all, 18 constituents were analyzed and 314 blank results were generated. Approximately 90 percent of the results were below censoring levels, indicating minimal contamination during this period. Overall, there were 30 detections, which represents approximately 10 percent of the results. Seventeen of these blank results were low-level detections of ammonia and phosphorus; the remaining 13 detections were distributed among eight other constituents including calcium, chloride, ammonia plus organic nitrogen, nitrate plus nitrite, orthophosphate, iron, manganese, and suspended sediment.

A constituent detection rate of 10 percent was deemed acceptable for this study. If a constituent was detected in greater than 10 percent of the combined equipment, vehicle, and field blanks, the results for that constituent were assessed for the potential to positively bias the environmental results. Five constituents exceeded the 10-percent blankdetection threshold including chloride (15 percent), ammonia (35 percent), phosphorus (50 percent), iron (15 percent), and suspended sediment (50 percent). For these constituents, blank detections were further evaluated on the basis of proximity to censoring levels and relevance to corresponding environmental concentrations. Environmental concentrations less than five times the median of the quantified blank detections generally were considered to have some potential for contamination (table 3). Concentrations of chloride and iron in all environmental samples were higher than the threshold and likely were not biased by contamination; therefore, these constituents were not listed in table 3 .

Ammonia was detected in one equipment blank, two vehicle blanks, and four field blanks with a median detection concentration of $0.01 \mathrm{mg} / \mathrm{L}$. Therefore, environmental ammonia concentrations greater than or equal to 0.01 and less than $0.05 \mathrm{mg} / \mathrm{L}$ were considered potentially biased. During water years 2016-17, approximately 53 percent of the environmental ammonia concentrations were within this range and should be interpreted with caution (table 3). Ammonia 
concentrations less than $0.01 \mathrm{mg} / \mathrm{L}$ (censored values) were not considered to be positively biased because they were reported as nondetections. A recent investigation indicated that laboratory processes at the NWQL, rather than field processes, are likely contributing to low-level detections of ammonia in blanks and a positive bias in environmental samples (U.S. Geological Survey, 2018). In the Triangle area, detections of ammonia in blanks notably decreased from water year 2016 (six detections) to water year 2017 (one detection).

Phosphorus was detected in three equipment blanks, three vehicle blanks, and four field blanks. The median detection was $0.006 \mathrm{mg} / \mathrm{L}$; therefore, a potential-contamination threshold of $0.03 \mathrm{mg} / \mathrm{L}$ was computed. Concentrations in environmental samples ranged from $<0.004$ to $0.917 \mathrm{mg} / \mathrm{L}$. Approximately 11 percent had concentrations less than the $0.03-\mathrm{mg} / \mathrm{L}$ threshold and thus may be biased (table 3 ). Contaminated sulfuric acid used to preserve the total phosphorus samples likely contributed to the high percentage of detections in blanks, particularly in water year 2016. In 2016, total phosphorus was detected in 8 of 10 TAWSMP blanks; during 2017, only 2 of 10 blanks had detections. The NWQL identified higher concentrations of total phosphorus in blank samples related to specific acid lot numbers. Approximately 83 percent of the phosphorus detections in the blank samples were associated with the identified sulfuric acid preservative lot numbers. The NWQL continues to monitor the sulfuric acid lots and investigate the potential causes of the low-level phosphorus contamination.

Suspended sediment was detected in two field blanks, and these detections were near the censoring level of $0.5 \mathrm{mg} / \mathrm{L}$. The median detection was $1.5 \mathrm{mg} / \mathrm{L}$; therefore, a potential-contamination threshold of $7.5 \mathrm{mg} / \mathrm{L}$ was computed. Concentrations in environmental samples ranged from 1 to $954 \mathrm{mg} / \mathrm{L}$. Approximately 37 percent had concentrations less than the $7.5-\mathrm{mg} / \mathrm{L}$ threshold and thus may be biased (table 3).

With the exception of the known contamination issues related to ammonia and total phosphorus, the number of blank detections was very low. Most of the detections for other constituents occurred infrequently, and concentrations were at or near constituent censoring levels, indicating negligible systematic positive bias.
The variability of sampling and analysis was assessed with 17 sets of field replicates that were analyzed for multiple constituents. Among the 17 sets of field replicates, there was a total of 159 replicate-result pairs. Paired concentrations with a relative percent difference (RPD, absolute difference times 100 divided by the average) less than 25 percent were considered to demonstrate acceptable reproducibility. Of the 159 replicate set pairs, approximately 98 percent had RPDs less than 25 percent.

The three occurrences of high RPDs were isolated and not representative of the dataset as a whole. Chlorophyll $a$, orthophosphate, and suspended sediment each had a single replicate set with an RPD greater than 25 percent. Large RPD values are common and accepted without further discussion when they result from small absolute differences near the constituent censoring level. For example, one orthophosphate replicate set had an RPD of 73.7; however, the absolute concentration difference was $0.007 \mathrm{mg} / \mathrm{L}$, and the censoring level was $0.004 \mathrm{mg} / \mathrm{L}$.

When the absolute concentration difference is greater than or equal to three times the censoring level and is associated with a large RPD, high variability is indicated. One chlorophyll $a$ replicate pair had an RPD of 30.6 percent and an absolute difference of 18.7 micrograms per liter $(\mu \mathrm{g} / \mathrm{L})$. This large absolute difference appeared to be an isolated occurrence but will continue to be monitored. One replicate pair for suspended sediment had an RPD of 32.3 percent and an absolute difference of $5 \mathrm{mg} / \mathrm{L}$. Constituents like suspended sediment are often difficult to replicate because particles are not homogenously distributed in the water. Suspended sediment generally showed acceptable reproducibility, but replicate sets will continue to be closely monitored. Overall, results for replicate pairs indicated acceptable reproducibility for all water-quality constituents measured during water years 2016 and 2017.

Additional sets of field triplicates were collected to assess the potential effects of switching laboratories on the chlorophyll $a$ record. Chlorophyll $a$ results reported by the NWQL were consistently higher and showed less variability than results obtained from Meritech, Inc. (table 4).

Table 3. Summary of selected constituent data observed in blank and environmental samples from the Triangle Area Water Supply Monitoring Project, October 2015 through September 2017.

[N, nitrogen; P, phosphorus; <, less than]

\begin{tabular}{|c|c|c|c|c|c|c|c|c|c|}
\hline \multirow{3}{*}{ Constituent } & \multirow{3}{*}{ Units } & \multirow{3}{*}{$\begin{array}{l}\text { Censoring } \\
\text { level }\end{array}$} & \multirow{3}{*}{$\begin{array}{l}\text { Number } \\
\text { of blanks } \\
\text { analyzed }\end{array}$} & \multicolumn{4}{|c|}{ Blanks } & \multirow{2}{*}{\multicolumn{2}{|c|}{ Environmental samples }} \\
\hline & & & & \multicolumn{4}{|c|}{ Blanks with detections } & & \\
\hline & & & & Number & Percent & $\begin{array}{l}\text { Range of } \\
\text { quantified } \\
\text { detections }\end{array}$ & $\begin{array}{l}5 \text { times the } \\
\text { median quantified } \\
\text { detection }\end{array}$ & $\begin{array}{l}\text { Range of } \\
\text { values }\end{array}$ & $\begin{array}{l}\text { Percent less than } 5 \text { times } \\
\text { the median concentration } \\
\text { detected in a blank }\end{array}$ \\
\hline $\begin{array}{l}\text { Ammonia, } \\
\text { filtered }\end{array}$ & $\begin{array}{c}\text { milligrams per } \\
\text { liter as } \mathrm{N}\end{array}$ & 0.01 & 20 & 7 & 35 & $0.01-0.02$ & 0.05 & $<0.01-0.12$ & 53.1 \\
\hline $\begin{array}{r}\text { Phosphorus, } \\
\text { unfiltered }\end{array}$ & $\begin{array}{c}\text { milligrams per } \\
\text { liter as } \mathrm{P}\end{array}$ & 0.004 & 20 & 10 & 50 & $0.004-0.009$ & 0.03 & $<0.004-0.917$ & 10.8 \\
\hline $\begin{array}{l}\text { Suspended } \\
\text { sediment }\end{array}$ & $\begin{array}{l}\text { milligrams per } \\
\text { liter }\end{array}$ & 0.5 & 4 & 2 & 50 & $1-2$ & 7.5 & $1-954$ & 37.3 \\
\hline
\end{tabular}


Table 4. Summary of chlorophyll a triplicate sample sets from the Triangle Area Water Supply Monitoring Project, October 2015 through September 2017.

[USGS, U.S. Geological Survey; NWQL, National Water Quality Laboratory; FK, Fork; R, River; NR, near; NC, North Carolina; CR, Creek; COV, coefficient of variation; - , not analyzed or not applicable]

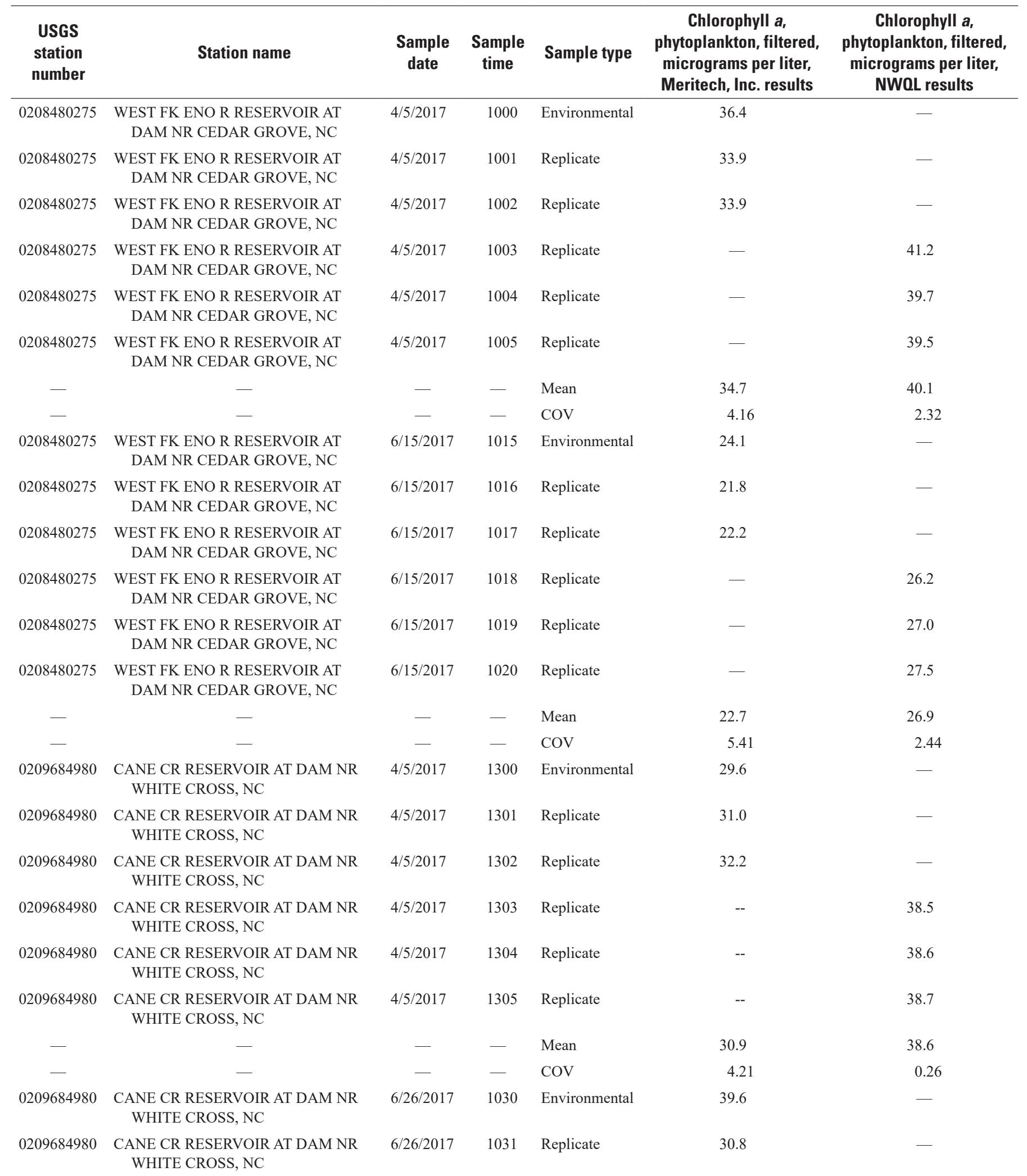


Table 4. Summary of chlorophyll a triplicate sample sets from the Triangle Area Water Supply Monitoring Project, 0ctober 2015 through September 2017.-Continued

[USGS, U.S. Geological Survey; NWQL, National Water Quality Laboratory; FK, Fork; R, River; NR, near; NC, North Carolina; CR, Creek; COV, coefficient of variation; - , not analyzed or not applicable]

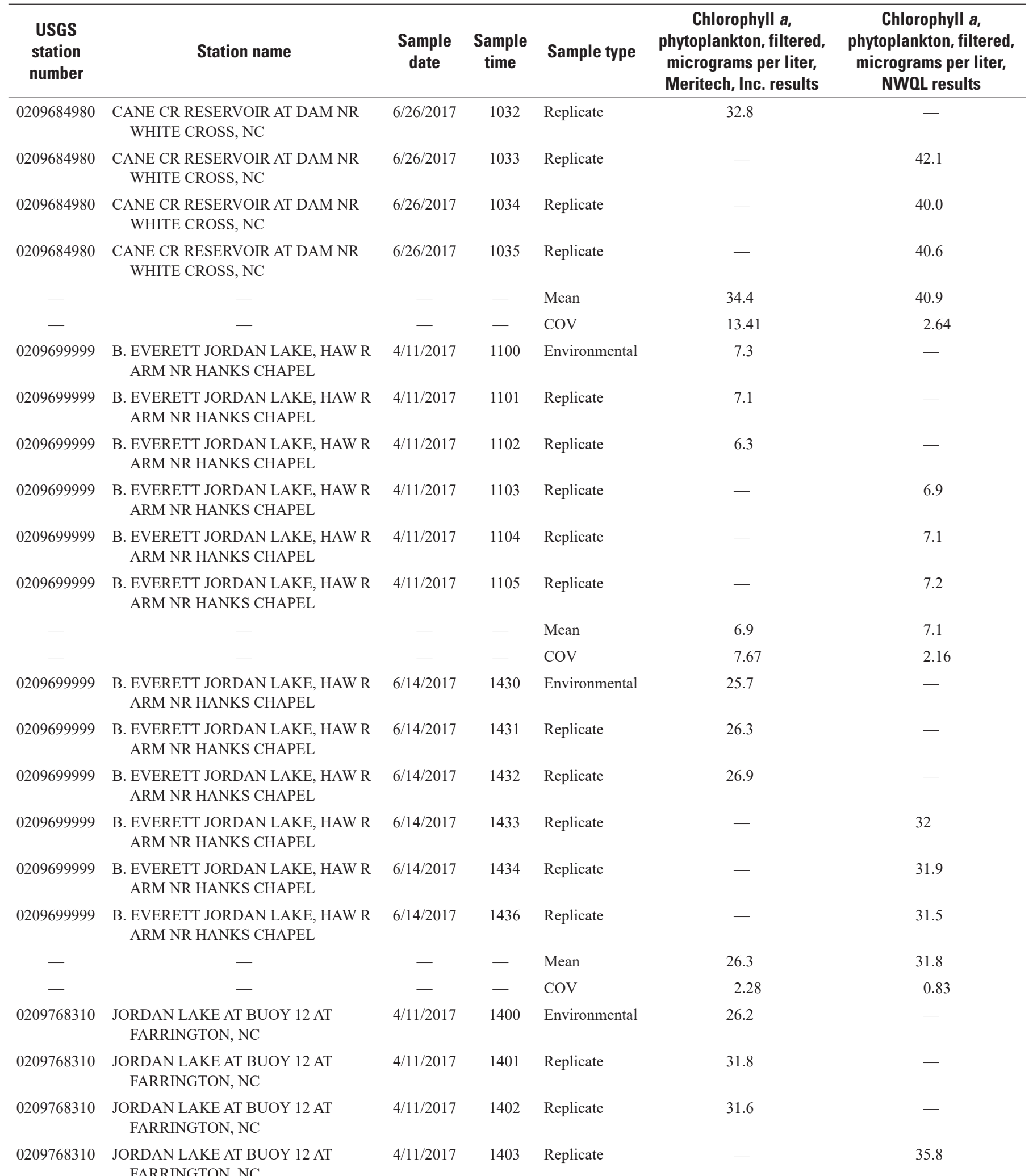


Table 4. Summary of chlorophyll a triplicate sample sets from the Triangle Area Water Supply Monitoring Project, October 2015 through September 2017.-Continued

[USGS, U.S. Geological Survey; NWQL, National Water Quality Laboratory; FK, Fork; R, River; NR, near; NC, North Carolina; CR, Creek; COV, coefficient of variation; - , not analyzed or not applicable]

\begin{tabular}{|c|c|c|c|c|c|c|}
\hline $\begin{array}{l}\text { USGS } \\
\text { station } \\
\text { number }\end{array}$ & Station name & $\begin{array}{l}\text { Sample } \\
\text { date }\end{array}$ & $\begin{array}{l}\text { Sample } \\
\text { time }\end{array}$ & Sample type & $\begin{array}{c}\text { Chlorophyll a, } \\
\text { phytoplankton, filtered, } \\
\text { micrograms per liter, } \\
\text { Meritech, Inc. results }\end{array}$ & $\begin{array}{c}\text { Chlorophyll } a \text {, } \\
\text { phytoplankton, filtered, } \\
\text { micrograms per liter, } \\
\text { NWOL results }\end{array}$ \\
\hline 0209768310 & $\begin{array}{l}\text { JORDAN LAKE AT BUOY } 12 \text { AT FAR- } \\
\text { RINGTON, NC }\end{array}$ & $4 / 11 / 2017$ & 1404 & Replicate & - & 34.1 \\
\hline 0209768310 & $\begin{array}{l}\text { JORDAN LAKE AT BUOY } 12 \text { AT FAR- } \\
\text { RINGTON, NC }\end{array}$ & $4 / 11 / 2017$ & 1406 & Replicate & - & 34.2 \\
\hline - & - & - & - & Mean & 29.9 & 34.7 \\
\hline- & - & - & - & $\mathrm{COV}$ & 10.64 & 2.75 \\
\hline 0209768310 & $\begin{array}{l}\text { JORDAN LAKE AT BUOY } 12 \text { AT FAR- } \\
\text { RINGTON, NC }\end{array}$ & 6/14/2017 & 1145 & Environmental & 28.8 & - \\
\hline 0209768310 & $\begin{array}{l}\text { JORDAN LAKE AT BUOY } 12 \text { AT FAR- } \\
\text { RINGTON, NC }\end{array}$ & 6/14/2017 & 1146 & Replicate & 29.2 & - \\
\hline 0209768310 & $\begin{array}{l}\text { JORDAN LAKE AT BUOY } 12 \text { AT FAR- } \\
\text { RINGTON, NC }\end{array}$ & 6/14/2017 & 1147 & Replicate & 32.3 & - \\
\hline 0209768310 & $\begin{array}{l}\text { JORDAN LAKE AT BUOY } 12 \text { AT FAR- } \\
\text { RINGTON, NC }\end{array}$ & 6/14/2017 & 1148 & Replicate & - & 37.3 \\
\hline 0209768310 & $\begin{array}{l}\text { JORDAN LAKE AT BUOY } 12 \text { AT FAR- } \\
\text { RINGTON, NC }\end{array}$ & 6/14/2017 & 1149 & Replicate & - & 37.9 \\
\hline 0209768310 & $\begin{array}{l}\text { JORDAN LAKE AT BUOY } 12 \text { AT FAR- } \\
\text { RINGTON, NC }\end{array}$ & 6/14/2017 & 1151 & Replicate & - & 38.3 \\
\hline - & - & - & - & Mean & 30.1 & 37.8 \\
\hline - & - & - & - & $\mathrm{COV}$ & 6.36 & 1.33 \\
\hline
\end{tabular}

\section{Streamflow}

Streamflow data collected at all 10 TAWSMP gaging stations were reviewed, quality assured, and published as print-ready water year summaries for water years 2016 and 2017 (https://wdr.water.usgs.gov/). Detailed data and summary statistics also are available online through the USGS NWISWeb database (U.S. Geological Survey, 2018; https://doi.org/10.5066/F7P55KJN). Streamflow is summarized below in terms of annual runoff compared with the longterm mean for each station's period of record. Annual runoff was computed by dividing the total average discharge (cubic feet per second) for the water year by the drainage area of the stream. The long-term mean was calculated using the annual runoff over the course of the entire period of record. It should be noted that the period of record varies among sites (table 1). At some sites, including New Hope Creek near Blands (site 12), Northeast Creek near Genlee (site 13), and Morgan Creek near Chapel Hill (site 16), a significant percentage of the instream flow consists of treated effluent from municipal water reclamation facilities. These continuous inputs contribute to higher instream baseflows and tend to mitigate the effects of drought on annual runoff.

Streamflow in water year 2016 was above the long-term mean at all gaging stations, with annual runoff values ranging from 15.8 to 34.2 inches (fig. $2 A$ ). In water year 2017, streamflow was slightly below the long-term mean at Cane Creek near Orange Grove (site 8), Morgan Creek near White Cross (site 14), Morgan Creek near Chapel Hill (site 16), and White Oak Creek (site 19), but slightly above the long-term mean at the remaining six sites. Annual runoff in water year 2017 ranged from 8.84 to 22.8 inches among the 10 gaging stations (fig. 2B). White Oak Creek (site 19) had periods of no flow during water year 2017. 

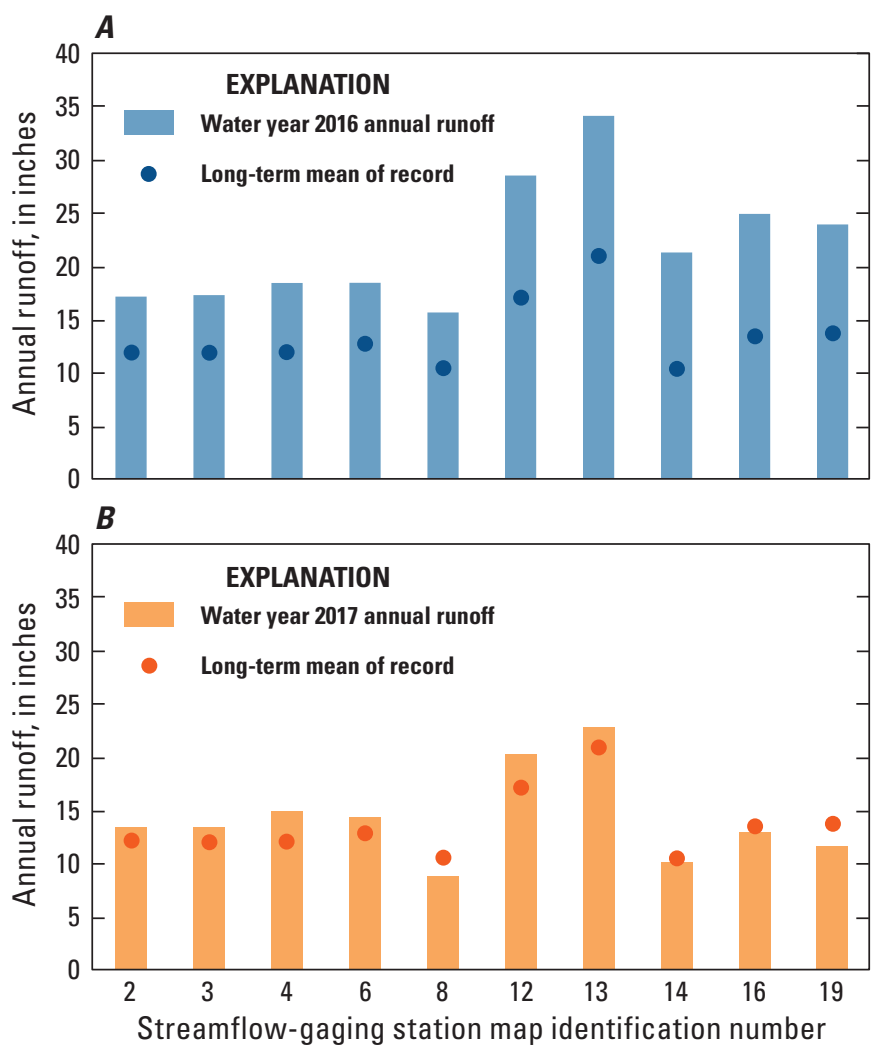

\section{Water Quality}

Water-quality data were reviewed and quality assured. The data are available online in Cain and others (2019; https://doi.org/10.5066/F71Z43MD). Ranges of concentrations observed at each site for 29 properties or constituents are presented in table 5 (available at https://doi.org/10.3133/ ofr20191077). Dissolved-oxygen percent saturation, hardness, and total nitrogen were computed by using USGS National Water Information System (NWIS) algorithms. Although the lake sites were sampled at multiple depths, only results from the photic zone and $1 \mathrm{~m}$ below the water surface are included in this report. Additional data for lake samples collected in near-bottom waters may be obtained from the USGS NWISWeb database (U.S. Geological Survey, 2018; https://doi.org/10.5066/F7P55KJN) or by request from the USGS South Atlantic Water Science Center (https://www.usgs.gov/centers/sa-water).

Instream water-quality thresholds have been adopted by the NCDWR for 11 constituents monitored by the TAWSMP (table 5). All project sampling sites are classified for water-supply use; therefore, applicable standards are the most stringent values established to protect freshwater aquatic life, water supply, or human health (North Carolina
Figure 2. Graphs showing annual runoff measured from (A) October 2015 through September 2016 (water year 2016) and (B) October 2016 through September 2017 (water year 2017), and the long-term mean runoff for the period of record at 10 streamflow-gaging stations in the Triangle area of North Carolina. Map identification numbers and the periods of record, which vary among stations, are given in table 1 .

Department of Environmental Quality, 2018). Individual observations that do not meet water-quality thresholds do not constitute violations of the standards nor indicate that the body of water is impaired; however, the thresholds are useful for comparative purposes. Maximum contaminant levels and National Secondary Drinking Water Regulations have been established by the U.S. Environmental Protection Agency for five of the monitored constituents (U.S. Environmental Protection Agency, 2018). These criteria are applicable only to treated potable water- not to raw water supplies - and are provided solely for reference.

Concentration ranges that are shown in table 5 in bold font indicate that at least one sample for the constituent exceeded a North Carolina water-quality threshold at that location. Exceedances of water-quality thresholds occurred at 19 of the 20 sites for at least one constituent. The only site to have no exceedances of any State water-quality thresholds was Haw River below B. Everett Jordan Lake dam near Moncure (site 22). Values exceeded thresholds for six waterquality constituents: dissolved oxygen, dissolved-oxygen percent saturation, $\mathrm{pH}$, water temperature, turbidity, and chlorophyll $a$ (table 5; fig. 3). No exceedances of State waterquality thresholds were observed for five constituents: hardness, chloride, fluoride, sulfate, and nitrate plus nitrite (table 5). 

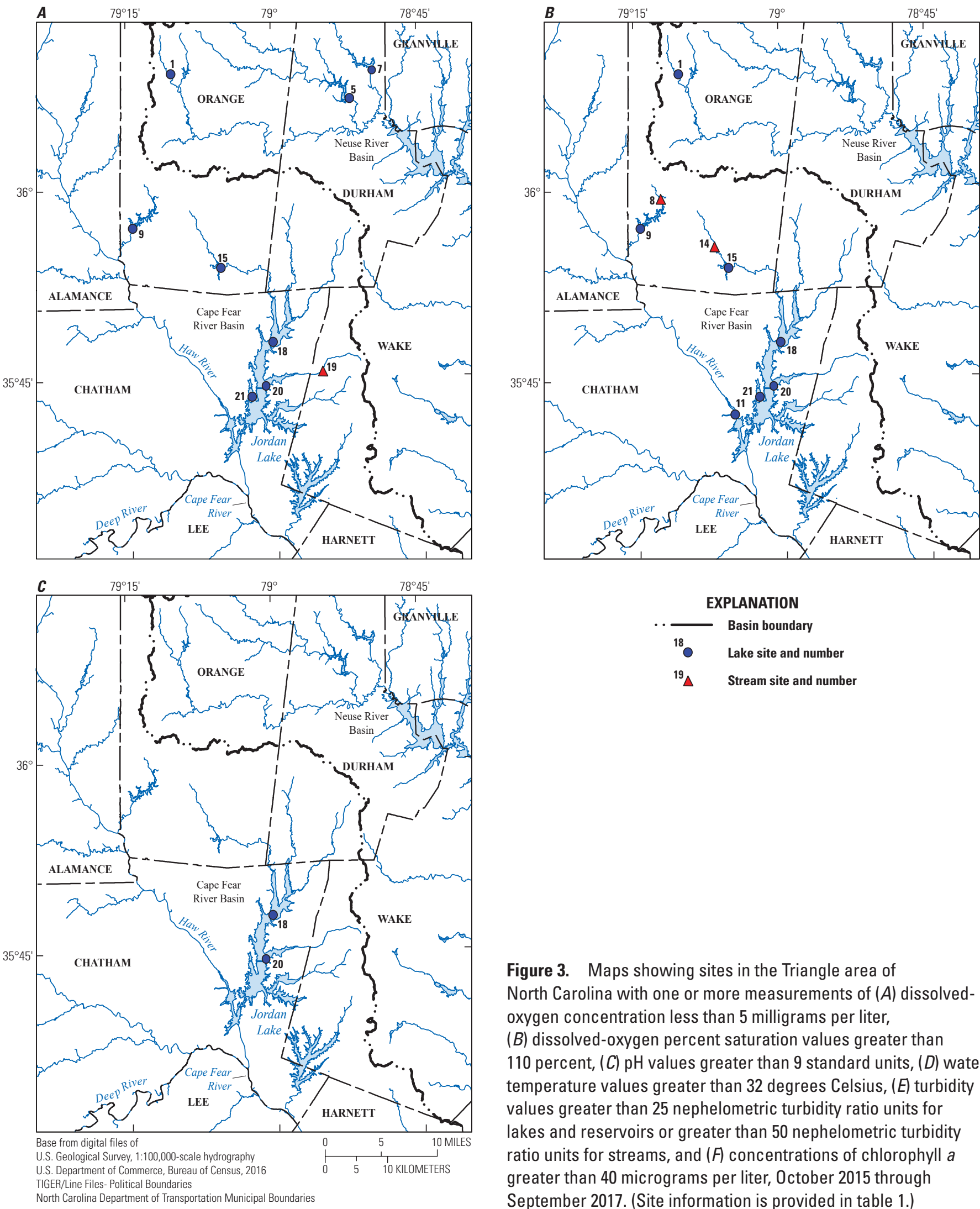

Figure 3. Maps showing sites in the Triangle area of

North Carolina with one or more measurements of $(A)$ dissolvedoxygen concentration less than 5 milligrams per liter, $(B)$ dissolved-oxygen percent saturation values greater than 110 percent, $(C) \mathrm{pH}$ values greater than 9 standard units, $(D)$ water temperature values greater than 32 degrees Celsius, $(E)$ turbidity values greater than 25 nephelometric turbidity ratio units for lakes and reservoirs or greater than 50 nephelometric turbidity ratio units for streams, and $(F)$ concentrations of chlorophyll $a$ greater than 40 micrograms per liter, 0ctober 2015 through September 2017. (Site information is provided in table 1.) 

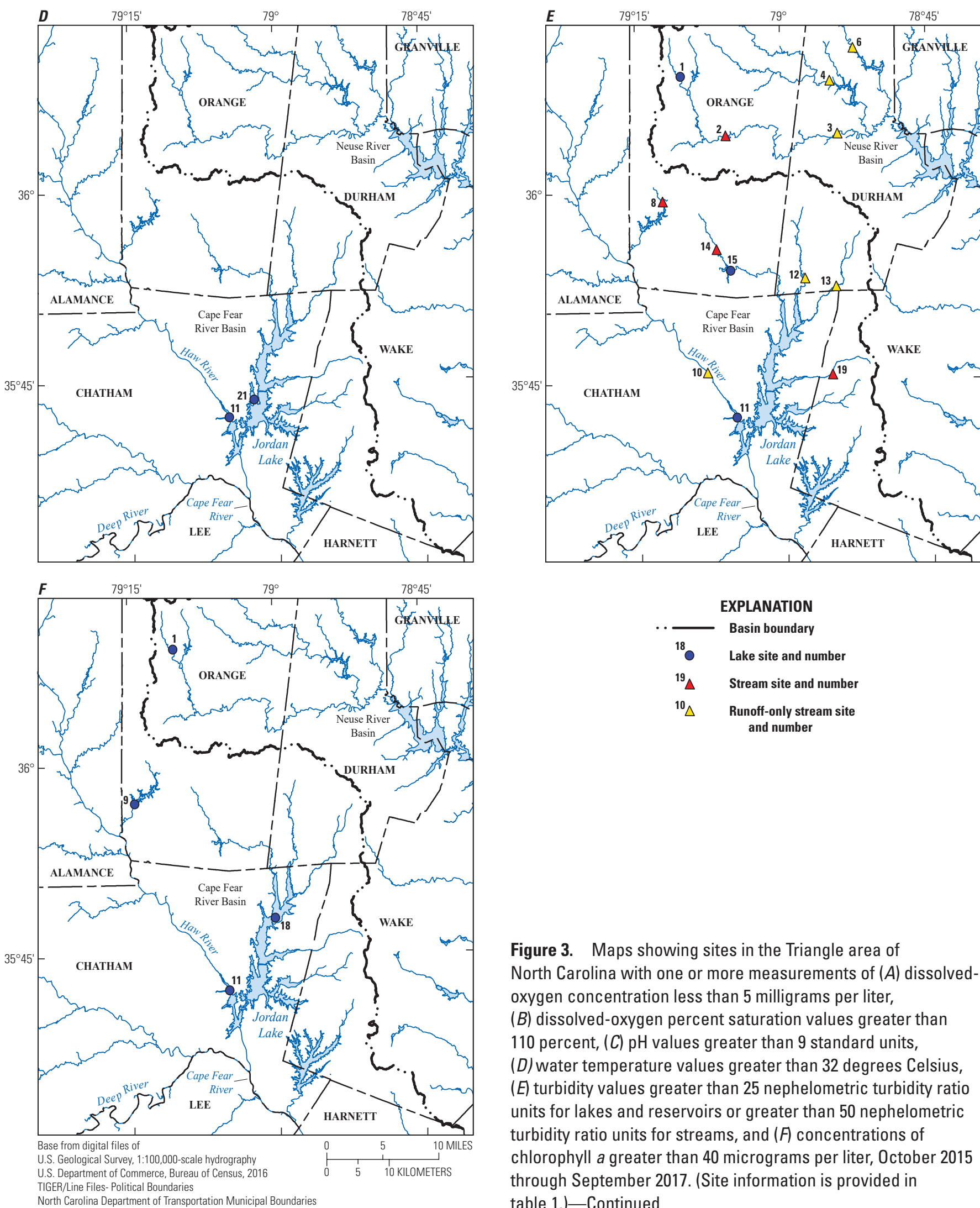

Figure 3. Maps showing sites in the Triangle area of North Carolina with one or more measurements of $(A)$ dissolvedoxygen concentration less than 5 milligrams per liter, $(B)$ dissolved-oxygen percent saturation values greater than 110 percent, $(C) \mathrm{pH}$ values greater than 9 standard units, (D) water temperature values greater than 32 degrees Celsius, $(E)$ turbidity values greater than 25 nephelometric turbidity ratio units for lakes and reservoirs or greater than 50 nephelometric turbidity ratio units for streams, and $(F)$ concentrations of chlorophyll a greater than 40 micrograms per liter, October 2015 through September 2017. (Site information is provided in table 1.)-Continued 


\section{Summary}

From October 2015 through September 2017, more than 5,000 individual measurements of water quality were made at 20 sites, and continuous records of streamflow were collected at 10 gaging stations in the Triangle Area Water Supply Monitoring Network. Streamflow was above normal during water year 2016 at all 10 sites. During water year 2017, streamflow was slightly below normal at Cane Creek near Orange Grove (site 8), Morgan Creek near White Cross (site 14), Morgan Creek near Chapel Hill (site 16), and White Oak Creek (site 19), and streamflow was slightly above normal at the remaining six sites. State water-quality thresholds exist for 11 of the 29 constituents measured. These thresholds were exceeded one or more times for dissolved oxygen, dissolvedoxygen percent saturation, $\mathrm{pH}$, water temperature, turbidity, and chlorophyll $a$. No samples exceeded thresholds for hardness, chloride, fluoride, sulfate, and nitrate plus nitrite. Approximately 18 percent of the samples collected consisted of quality-control samples. Overall, 10 percent of the blank results exceeded censoring levels. The 30 blank detections were distributed among 10 different constituents; most of these occurred rarely and at concentrations near laboratory reporting levels. Three constituents - ammonia, total phosphorus, and suspended sediment - were detected frequently and at concentrations that could positively bias a subset of the environmental samples. Approximately 98 percent of replicate pairs had relative percent differences less than 25 percent. Only one replicate pair-suspended sediment - indicated high variability and will continue to be monitored.

\section{References Cited}

American Society for Testing and Materials, 2002, ASTM D3977-97, standard test methods for determining sediment concentration in water samples: West Conshohocken, Pa., ASTM International, Annual Book of ASTM Standards, v. 11.02.

Arar, E.J., and Collins, G.B., 1997, Method 445.0 - In vitro determination of chlorophyll $a$ and pheophytin a in marine and freshwater algae by fluorescence (revision 1.2): Cincinnati, Ohio, U.S. Environmental Protection Agency, 21 p., accessed August 6, 2018, at https://cfpub.epa.gov/si/ si_public_record_report.cfm?dirEntryId $=309417$.

Cain, J.L., Pfeifle, C.A., and Rasmussen, R.B., 2019, Associated data for the Triangle Area Water Supply Monitoring Project, North Carolina, October 2015September 2017: U.S. Geological Survey data release, https://doi.org/10.5066/F71Z43MD.
Clesceri, L.S., Greenberg, A.E., and Eaton, A.D., eds., 1998a, High temperature combustion, part 5310B of Standard methods for the examination of water and wastewater (20th ed.): Washington, D.C., American Public Health Association, American Water Works Association, and Water Environment Federation, p. 5-20 to 5-21.

Clesceri, L.S., Greenberg, A.E., and Eaton, A.D., eds., 1998b, Metals plasma emission spectroscopy, part 3120 of Standard methods for the examination of water and wastewater (20th ed.): Washington, D.C., American Public Health Association, American Water Works Association, and Water Environment Federation, p. 3-37 to 3-43.

Fishman, M.J., ed., 1993, Methods of analysis by the U.S. Geological Survey National Water Quality LaboratoryDetermination of inorganic and organic constituents in water and fluvial sediments: U.S. Geological Survey Open-File Report 93-125, 217 p. [Also available at https://doi.org/10.3133/ofr93125.]

Fishman, M.J., and Friedman, L.C., eds., 1989, Methods for determination of inorganic substances in water and fluvial sediments: U.S. Geological Survey Techniques of WaterResources Investigations, book 5, chap. A1, 545 p. [Also available at https://doi.org/10.3133/twri05A1.]

Garbarino, J.R., and Struzeski, T.M., 1998, Methods of analysis by the U.S. Geological Survey National Water Quality Laboratory-Determination of elements in whole-water digests using inductively coupled plasma-optical emission spectrometry and inductively coupled plasma-mass spectrometry: U.S. Geological Survey Open-File Report 98-165, 101 p. [Also available at https://doi.org/10.3133/ofr98165.]

Hambrook Berkman, J.A., and Canova, M.G., 2007, Algal biomass indicators (ver. 1.0, August 2007): U.S. Geological Survey Techniques of Water-Resources Investigations, book 9, chap. A7, sec. 7.4, 82 p., accessed June 28, 2018, at https://pubs.water.usgs.gov/twri9A7/.

North Carolina Department of Environmental Quality, 2018, Surface water standards, NC surface water quality standards tables: North Carolina Department of Environmental Quality, Division of Water Resources, accessed April 3, 2018, at http://deq.nc.gov/about/divisions/waterresources/planning/classification-standards/surface-waterstandards\#WQSTables.

Oblinger, C.J., 2004, Triangle Area Supply Monitoring Project, October 1988 through September 2001, North CarolinaDescription of the water-quality network, sampling and analysis methods, and quality-assurance practices: U.S. Geological Survey Open-File Report 2004-1278, 56 p. [Also available at https://doi.org/10.3133/ofr20041278.] 
O’Dell, J.W., ed., 1993, Method 180.1-Determination of turbidity by nephelometry (revision 2.0): Cincinnati, Ohio, U.S. Environmental Protection Agency, 9 p., accessed August 6, 2018, at https://www.epa.gov/sites/production/ files/2015-08/documents/method_180-1_1993.pdf.

Patton, C. J., and Kryskalla, J. R., 2011, Colorimetric determination of nitrate plus nitrite in water by enzymatic reduction, automated discrete analyzer methods: U.S. Geological Survey Techniques and Methods, book 5, chap. B8, 34 p. [Also available at https://doi.org/10.3133/tm5B8.]

Patton, C.J., and Truitt, E.P., 2000, Methods of analysis by the U.S. Geological Survey National Water Quality LaboratoryDetermination of ammonium plus organic nitrogen by a Kjeldahl digestion method and an automated photometric finish that includes digest cleanup by gas diffusion: U.S. Geological Survey Open-File Report 00-170, 31 p. [Also available at https://doi.org/10.3133/ofr00170.]

Radtke, D.B., Davis, J.V., and Wilde, F.D., 2005, Specific electrical conductance (ver. 1.2, August 2005): U.S. Geological Survey Techniques of Water-Resources Investigations, book 9, chap. A6, sec. 6.3, 20 p., accessed June 28, 2018, at https://pubs.water.usgs.gov/twri9A6/.

Ritz, G.F., and Collins, J.A., 2008, pH (ver. 2.0, October 2008): U.S. Geological Survey Techniques of Water-Resources Investigations, book 9, chap. A6, sec. 6.4, 28 p., accessed June 28, 2018, at https://pubs.water.usgs.gov/twri9A6/.

Rounds, S.A., 2012, Alkalinity and acid neutralizing capacity (ver. 4.0, September 2012): U.S. Geological Survey Techniques of Water-Resources Investigations, book 9 , chap. A6, sec. 6.6, 43 p., accessed June 28, 2018, at https://pubs.water.usgs.gov/twri9A6/.
Rounds, S.A., Wilde, F.D., and Ritz, G.F., 2013, Dissolved oxygen (ver. 3.0, September 2013): U.S. Geological Survey Techniques of Water-Resources Investigations, book 9 , chap. A6., sec. 6.2, 55 p., accessed June 28, 2018, at https://pubs.water.usgs.gov/twri9A6/.

U.S. Environmental Protection Agency, 1993, Method 365.1Determination of phosphorus by semi-automated colorimetry (revision 2.0): Cincinnati, Ohio, U.S. Environmental Protection Agency, 16 p.

U.S. Environmental Protection Agency, 2018, Secondary Drinking Water Standards - Guidance for nuisance chemicals: U.S. Environmental Protection Agency web page, accessed April 3, 2018, at https://www.epa.gov/ dwstandardsregulations/secondary-drinking-waterstandards-guidance-nuisance-chemicals.

U.S. Geological Survey, 2006, Collection of water samples (ver. 2.0, September 2006): U.S. Geological Survey Techniques of Water-Resources Investigations, book 9, chap. A4, 160 p., accessed June 28, 2018, at https://pubs.water.usgs.gov/twri9A4/.

U.S. Geological Survey, 2018, USGS water data for the Nation: U.S. Geological Survey National Water Information System database, accessed June 28, 2018, at https://doi.org/10.5066/F7P55KJN.

Wilde, F.D., 2006, Temperature (ver. 2.0, March 2006): U.S. Geological Survey Techniques of Water-Resources Investigations, book 9, chap. A6, sec. 6.1, 20 p., accessed June 28, 2018, at https://pubs.water.usgs.gov/twri9A6/. 



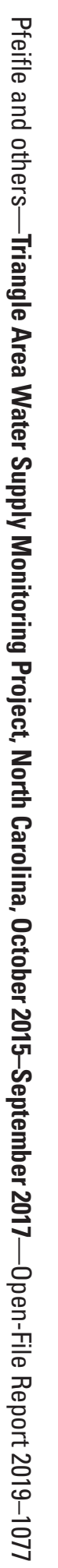

